\title{
A MORTE DO PAI E O DECLÍNIO DA FUNÇÃO DE PROFESSOR
}

Antônio Eustáquio FERREIRA ${ }^{1}$

RESUMO: O presente artigo é uma reflexão acerca de alguns aspectos que contribuíram para a "morte" do pai e o declínio da função de professor. Analisamos os fatores que influenciaram as transformações na constituição da noção de pai em Freud, na construção do conceito de função paterna em Lacan, e o reflexo disso no lugar ocupado pelo professor enquanto operador simbólico da Lei. Explicitamos os efeitos produzidos nas relações entre professores e estudantes nas instituições educacionais. $\mathrm{O}$ trabalho propõe explicitar como o professor, enquanto operador simbólico da Lei ocupa o lugar do pai e também perde sua função. Esta investigação é resultado de estudo bibliográfico envolvendo a noção de pai, de castração, dos Nomes-do-Pai e o conceito de função paterna. Finalizamos explicitando como os fenômenos acima elencados foram enfraquecendo e confundindo o simbolismo paterno e refletiram no declínio da função de professor.

PALAVRAS-CHAVE: Noção de pai. Castração. Função paterna.

\section{Introdução}

Para investigarmos a morte do pai e o declínio da função de professor, percorreremos parte do caminho pelo qual Freud constituiu a noção de pai. Para tanto, recorreremos a algumas de suas obras, tais como: “Édipo” Freud (1996a), “Totem e Tabu” Freud (1996b) e “Moisés e Monoteísmo” Freud (1996d), obviamente relacionando-as às demais, nas quais ele aborda a mesma questão, ou seja, a noção de pai. Lacan (1995; 2005) também fará parte desse percurso, e neste caso, com a construção do conceito de função paterna. As obras de Lacan serão "O Seminário - livro 4, A relação de objeto” (1995) e “Nomes-do-Pai” (2005).

\section{Breve relato sobre a noção de pai de Freud a Lacan}

A alternativa para analisar as palavras e fórmulas utilizadas por Freud e Lacan como noção é balizada nas ideias de Dor (1991), Lacan (1995; 2005), Laplanche e Pontalis (2001) e Pereira (2008). De Dor (1991, p.14), porque tratou da noção de pai no campo psicanalítico, como ela interferiu no espaço conceitual da psicanálise. O referido

\footnotetext{
${ }^{1}$ Doutor em Psicologia. PUC Goiás - Pontifícia Universidade Católica de Goiás. Professor convidado no Centro de Orientação e Organização Psicanalítica CORPO. Goiânia - GO - Brasil. 74605-010 eustaquioaf@gmail.com.
} 
autor demonstrou como o pai é uma “entidade simbólica que ordena uma função”. Portanto, o modo preponderante de existência simbólica dessa entidade, o pai, autorizao universalmente à estruturação dos sujeitos que com ele se relaciona independentemente do sexo. Logo, aos seres de linguagem não resta saída, a não ser se submeterem ao que lhes é determinado pela função simbólica paterna, que os forçam a uma experiência de sexualidade. Já Lacan (1995) considerou como noções as palavras de: fobia, objeto e fetiche, apenas para citar alguns exemplos. Lacan (2005) acreditava ter sido positiva a questão de levar para seu seminário a noção do plural dos Nomes-doPai, estudar a função dos nomes do pai. A motivação de Lacan pode ser identificada quanto às questões de suas reconstruções, de seu retorno a Freud e suas significativas contribuições para a psicanálise. No caso de Laplanche \& Pontalis (2001), eles explicitaram que as obras de Freud foram se enriquecendo porque ele se apoiou na psicologia, na psicopatologia e na neurofisiologia de seu tempo. Porém, foi na língua alemã que ele encontrou as palavras e fórmulas ideais para seu trabalho. Assim, os autores buscaram analisar os elementos utilizados por Freud, identificando as noções, ou seja, o conjunto de conceitos idealizados por Freud para ilustrar suas investigações. Por fim, Pereira (2008) revelou que Freud não dedicou uma investigação exclusiva acerca do tema do desamparo, cuja noção foi objeto de investigação do primeiro. Portanto, Pereira (2008) também buscou uma noção da palavra no pensamento freudiano. O autor justificou sua opção pela alternativa da noção, asseverando que Freud revisava suas obras e não raro "derrubava de uma só vez o conjunto de seu sistema teórico anterior, por vezes longamente elaborado” (Pereira, 2008, p.126). O psicanalista assinalou como exemplo, a obra de Freud "Projeto", de 1895, que traz a ideia de localização dos processos psíquicos, como sendo na célula nervosa. Ao passo que, quatro anos antes, em outra investigação, Freud já havia criticado essa possibilidade de identificação física e cerebral desses processos.

A noção de pai na obra em Freud (1996a) se inicia pelo mito de Édipo. Ele investiga ilustrando o caso de uma criança do sexo masculino que direcionou um investimento objetal pela mãe. Essa energia psíquica estaria ligada à representação do seio materno. Esse evento durava até o momento em que os desejos sexuais do menino pela mãe se fortaleciam, e a criança percebia o pai como obstáculo em relação a esses desejos. A relação com o pai, que antes era de identificação, passa agora a ser de ódio. Segundo Freud (1996a) seria a gênese do complexo de Édipo. Seria o momento do surgimento, no menino, do desejo de eliminar o pai e ocupar o seu lugar ao lado da mãe. 
Nesse momento, a relação do menino com o pai se transforma, pois ele amará e odiará, em um movimento idêntico a mesma pessoa, ou seja, o pai. Segundo Freud (1996a), o conjunto do complexo de Édipo positivo simples, num menino, passa a conter dois elementos: a atitude ambivalente do menino para com o pai e a relação objetal afetuosa com a mãe.

Freud (1996a) assevera que com o fim do investimento objetal do menino pela mãe, o vazio que fica poderá ser ocupado por dois eventos. No primeiro evento, o menino poderá se identificar com a mãe, no segundo, fortalecer sua identificação com o pai. Este último resultado, considerado pelo autor como o mais comum, possibilitaria a manutenção da relação afetuosa do menino com a mãe. Esse desfecho do complexo de Édipo solidificaria a forma como esse menino se situaria em relação ao seu sexo biológico. Para o caso da menina, o desfecho promoveria um fortalecimento de sua identificação com a mãe, evento que consolidaria o modo de ser feminino da criança.

A castração, inserida no interior do complexo de Édipo, tem a função de ordenar as pulsões. A castração ocorre num momento em que a criança percebe a dessemelhança entre os sexos e também a representação psíquica de tal evento. Freud (1996a) exemplifica que o pequeno Hans dizia que em tudo haveria algo do pênis. Seria a fase em que a criança se interessaria pelos seus órgãos genitais. O interesse foi demonstrado pelo menino quando manipulava seus órgãos genitais. Naquele momento, ele percebia que seus cuidadores não o apoiavam. A mensagem negativa vinha das mulheres, segundo Freud (1996a), pois elas o ameaçavam buscando na figura do pai ou do médico, parceiros que funcionavam como executores da mutilação do órgão que tanto o menino valorizava. As mulheres também redirecionavam a ameaça para outro membro, no caso, a mão do menino, que era para que ele não manipulasse seu órgão genital. No entanto, a ameaça à castração seria maior, pelo fato de a criança urinar na cama e não poder ser higienizada, pois seus cuidadores desconfiavam que o fato de urinar na cama pudesse ser prova de que a criança estaria inadequadamente interessada em seu órgão genital e ainda, que esse fato estaria ligado a uma excitação física genital identificada à dos adultos, uma espécie de ejaculação involuntária que ocorre durante o sono. Nesse sentido, Freud (1996a) acreditava ser essa ameaça de castração a responsável pelo desmantelamento da estrutura fálica da criança.

Com relação à eficácia da ameaça, o psicanalista vienense apontou uma diferença de funcionamento no menino. Ele, o menino, não aceita terminantemente a ameaça, porque quem o ameaça, a mãe, não é o modelo e sim seu objeto de desejo. 
Assim, há necessidade de a mãe chamar o pai. Dessa forma, ela introduz o pai na relação. O pai que já ocupava as posições de rival e modelo, agora entra na relação como magistrado castigador. Dor (1991) alerta que a mãe introduz o pai como um “diplomata”, como um “embaixador”, que entra na relação para a confirmação da autoridade perante a “comunidade estrangeira mãe-filho”. (DOR, 1991, p.14).

Essa organização efetivada pelo complexo de Édipo ocupa um ambiente simbólico. Trata-se de uma representação simbólica. Esta representação seria uma porta de acesso à cultura. Essa porta possibilitaria à criança se identificar com os valores sociais, assimilar a proibição do incesto e se constituir como sujeito de desejo.

Em “Totem e Tabu”, Freud (1996b) analisou os comportamentos nos relacionamentos das tribos australianas, seus pensamentos e atitudes para com reis, chefes, inimigos e comparou com as mesmas atitudes em relação aos pais. $\mathrm{O}$ autor percebeu que o poder do pai morto ficou fortalecido. Dessa forma, não havia necessidade de força para manter a lei, porque ela já estava internalizada. O pai morto substituiu o líder opressor e se transformou em um símbolo que teria relação com a lei. Então, a função do pai seria simbólica. Portanto, a existência de um pai não era garantia da efetivação da lei.

Nesse sentido, na obra acima mencionada, o autor aponta a noção de pai como àquele que introduz a rede simbólica, o que garante o nome da lei. Nas duas obras de Freud, “Totem e Tabu” e "Édipo”, o pai que surge fortalecido enquanto lei é o pai morto. Os filhos só o reconhecem quando morto, ou seja, surge o pai quando ele, o tirano, morre.

Freud (1996b) revela que havia um pai aterrorizante e que desfrutava de todas as mulheres. Para esse homem não havia nenhuma lei, nenhum tabu que o impedisse de ter relações sexuais com qualquer mulher da tribo. Com sua presença física ele impedia os demais de terem relações sexuais dentro do grupo. Segundo Freud (1996b), seria um período da humanidade, quando esta era formada por grupos de mulheres dominadas por homens. Esses machos líderes afastavam os filhos das mulheres, quando estes chegavam à maturidade sexual. A penalidade para quem não obedecesse às regras seria a castração e a morte.

Ainda segundo o autor, houve uma revolta de um grupo de filhos. Eles se uniram, mataram o pai e fizeram um banquete com o corpo, consumindo suas partes. Assim, acreditavam que, dessa forma, a força do pai também seria por eles adquirida. No entanto, o conflito persistia, pois os filhos, concorrentes entre si, ainda teriam o 
desejo de ocupar o lugar do pai. Porém, sozinhos não poderiam empreender tal ação. Dessa forma, o grupo se deparou com uma regra que não foi imposta arbitrariamente, mas que foi resultado de uma proibição real aos seus desejos incestuosos. Não poderiam ocupar o lugar do pai individualmente, mas sim com a ajuda do grupo. Nesse sentido, o limite seria ter que se submeter ao grupo. No entanto, o desejo de matar o pai e ocupar seu lugar não deixaria de existir. Assim, deveriam se submeter também à nova ordem. Portanto, deveriam desistir do lugar do pai e dos benefícios desse lugar, principalmente em relação às mulheres, porque não poderiam possuí-las. Dito de outra maneira, o casamento entre eles mesmos, bem como as relações sexuais da mesma forma, estavam proibidos.

O motivo que levou os filhos a desistirem de ocupar o lugar do pai, deixa-os com um sentimento de abandono, com um sentimento de culpa pelo assassinato do pai. Dessa culpa nascem dois tabus do sistema do totemismo, ou seja, dois desejos correspondentes aos desejos reprimidos do complexo de Édipo, quais sejam: o desejo de matar o pai e o desejo de possuir a mãe.

No sistema do totemismo, um animal ocupa o lugar do pai morto. Essa substituição provoca um sentimento de culpa. Segundo Freud (1996b), a substituição seria uma tentativa de acalmar o sentimento de culpa. Assim, os filhos passam a tratar o substituto com respeito. A culpa também traz para a relação com o substituto, uma reconciliação com o pai. Essas características irão influenciar a natureza da religião.

A religião totêmica surge do sentimento de culpa, mas também como forma de abrandar esse sentimento e harmonizar a relação com o pai, o que Freud (1996b) considerou como um adiamento de obediência. $\mathrm{O}$ autor também revelou que $\mathrm{o}$ surgimento das demais religiões foram experiências para tentar resolver o mesmo problema. Apesar da diversidade cultural e métodos adotados, a finalidade das religiões seria a mesma, ou seja, apaziguar o problema do sentimento filial de culpa. Um arrependimento que não deu descanso à humanidade. Apesar da vitoria dos impulsos que levaram ao assassinato do pai, o que restou foi um sentimento de fraternidade, pois ninguém queria ocupar o lugar do pai e se tornar um novo tirano. $\mathrm{O}$ assassinato e o arrependimento dos filhos propiciaram o nascimento da sociedade e da religião.

O sentimento de culpa persiste no meio do clã. Nesse sentido, o novo substituto do pai é tratado como se fosse membro da comunidade. Há uma identificação com esse deus, por parte dos componentes do clã que participam do ritual a ele endereçado. Freud (1996b) fez nova comparação enfatizando que, segundo a psicanálise, surge uma 
concepção de Deus que se torna o centro das atenções e que controla a vida religiosa. Esse deus do totemismo, formatado à semelhança do pai, torna-se o Deus pai glorificado. Ele representa o sacrifício primitivo: como Deus e como vítima. Vale ressaltar que antes o Totem era representado por um animal, agora os súditos resgatam sua forma humana. Portanto, segundo o autor, os filhos restauram a forma humana do pai e, com isso, podem sentir saudade desse pai. Todavia, esse resgate ainda traria complexidade na relação com a divindade em forma humana. O lugar de autoridade, antes ocupado por um pai, agora substituído por um deus, implica em uma organização na sociedade, que passa a ser patriarcal.

Freud (1996b) afirma que para a psicanálise o Deus individual é constituído a semelhança do pai e a relação que cada indivíduo tem com Deus depende de sua relação com o pai. A nostalgia ao pai permitiu o surgimento de um ideal que corporificava o poder do pai da horda. Freud (1996b) assinala que significativas mudanças culturais, sem apontá-las, inviabilizaram a harmonia de uma sociedade igualitária. Os homens passam a adorar vários deuses. No entanto, o pai primevo passou a ser o deus de quem o grupo descendia e se torna ícone de autoridade.

Freud (1996b) finaliza asseverando que, do complexo de Édipo, surge a base religiosa. Essa ideia estaria de acordo com a descoberta da psicanálise, de que o complexo de Édipo é o centro geral das neuroses. Segundo Laplanche \& Pontalis (2001, p.296), neurose é uma doença psicogênica “em que os sintomas são a expressão simbólica de um conflito psíquico que tem raízes na história infantil do sujeito e constitui compromissos entre o desejo e a defesa.” Nesse sentido, Freud (1996b) afirma que a imagem do pai é a mais importante na vida de uma criança ou da de um homem e que esse fato é mais nítido no mito grego de Édipo. No entanto, o sentimento de admiração da criança pelo pai passa a ser de ódio e surge o desejo de eliminá-lo para ocupar seu lugar, o que Freud (1996b) denominou de ambivalência emocional. E o psicanalista vienense considera a "relação de uma criança com os pais, dominada como é por desejos incestuosos, como o complexo nuclear das neuroses” (FREUD, 1996b, p.16).

Na obra "Moisés e o monoteísmo" Freud (1996d), o primeiro relato acerca do pai, tem início com a narrativa do excerto do livro de Otto Rank, publicado em 1909, cuja história foi sobre a glorificação de heróis dos povos civilizados, um relato de como eles eram transformados em lendas e em contos fabulosos. O herói, geralmente era filho de um rei, e o histórico de sua gestação era repleto de complicações, principalmente 
oriundas das mensagens dos oráculos acerca do perigo que o nascimento deles traria para o pai. Assim sendo, deveria ser morto, por ordem do pai ou de seu representante. Geralmente, esse herói era condenado às “vontades” das águas, pois era colocado em um cesto e deixado à deriva. No entanto, ele geralmente era salvo, sobrevivia, crescia e após um período de aprendizado e descoberta da nobreza do pai, conseguia se vingar e ainda era reconhecido.

O autor utilizou o mito de Sargão de Agade para ilustrar a trajetória de um herói. Sargão teria sido abandonado no Eufrates, mas o "tirador de água” "Akki” o teria encontrado. Fortalecido pelo modo como foi criado por "Akki” e escolhido pela deusa “Istar”, Sargão se transformou em um rei. Essa narrativa foi para explicitar que heróis como Moisés e Édipo fizeram parte das histórias de Rank. Em todos os casos, os heróis foram personagens que enfrentaram e venceram os pais.

Os personagens dos contos das histórias de Rank também surgem de uma forma diferente, no ambiente do lar, no qual ocorre um 'romance familiar' da criança Freud (1996d). Para a criança, existe um mundo povoado de personagens de contos de fadas, ou seja, de reis e de rainhas. Esses personagens representam os pais. Num período da vida da criança há uma supervalorização do pai. Em outro, quando ela descobre que seus heróis são na verdade seus rivais, a criança se afasta deles e se posiciona contra o pai. Desta forma, as duas famílias - a do conto de fadas e da realidade - serão resultantes da família que surge nas fases da vida da criança.

Freud (1996d), em “Moisés e Monoteísmo” inicia sua pesquisa sobre a morte de Moisés, investigando a origem de seu nome. Conforme comentado anteriormente, a origem do nome de Moisés faz parte da narrativa de Rank. Entretanto, o pesquisador revelou, explorando excerto da obra de J. H. Breasted, que o nome Moisés era egípcio e não poderia ter ligação com a expressão: “porque das águas o tenho tirado”, como foi apresentado. O autor demonstrou que a palavra "mose” significa “criança” e é abreviação de ”Amon-mose”. “Amon-mose” significa “Amon-uma-criança”, ou "Ptahmose", do mesmo modo significando "Ptah-uma-criança”, e estas ainda seriam abreviações de “Amon-(deu)-uma-criança”, ou "Ptah-(deu)-uma-criança”. Freud (1996d) acreditava que o pai de Moisés incluiu ao nome do filho elementos dos nomes de deuses, tais como: Amon ou Ptah. Portanto, a criança foi chamada de "Mose”, sendo que o 's' final foi acrescentado da “tradução grega do Antigo Testamento” (FREUD, 1996d, p.5). 
Na obra "Moisés e o monoteísmo" Freud (1996d), o assassinato do pai é retomado como centro para investigação da morte de Moisés. Moisés ocupou o lugar do pai e foi assassinado. Importante ressaltar a questão do nome, porque é a isso que Freud (1996d) intentava com seu artigo, isto é, a sua aplicação em psicanálise.

Na lenda de Moisés, ocorreram alguns fatores diferenciados dos outros personagens heróicos das histórias de Rank. Moisés saiu de uma família humilde para ser encontrado e criado por uma família real. No entanto, Freud (1996d) revelou que a criação da lenda deve ser atribuída aos judeus, uma vez que os egípcios não tinham motivo para criar um herói feito Moisés. Nesse sentido, a referida lenda estaria conectada a uma história de nascimento, à imagem do líder do povo judeu. Entretanto, ficaria sem sentido criar uma história cujo herói fosse um estrangeiro para os judeus. Porém, Moisés foi colocado nas mesmas situações das figuras heróicas anteriores, ou seja, apesar de ter sido abandonado e ficado à mercê de perigos externos, foi encontrado e conseguiu sobreviver, transformando-se em um líder.

Freud (1996d) trabalhou no sentido de afirmar que Moisés era egípcio e fazia parte da aristocracia. A lenda foi idealizada de modo invertido para aproximar Moisés dos judeus. O psicanalista vienense argumentou que haveria motivos para que a história fosse inventada dessa forma. Talvez atender às necessidades de um povo judeu por um egípcio, ou anunciar e disseminar a religião de Akhenaten, mestre de Moisés. Assim sendo, Moisés foi “apresentado” como egípcio, pois seria o educador e legislador do povo de Israel, além de encarregado para impor-lhes a nova religião. Nova religião, rigorosa e de um só Deus. Diferente da religião do Egito, com várias divindades.

Com o fim do reinado de Akhenaten, Moisés guiou o povo para fora do Egito, mas foi por ele sacrificado, pois utilizou um método mais rigoroso do que o de seu mestre para impor-lhes a fé em seu Deus, qual seja, obrigou-os a acreditar em um novo e único Deus.

Freud (1996d) relatou que o povo, guiado por Moisés, encontrou-se com um grupo semita. Da união do deus dos semitas, denominado de YHWH, um deus vulcânico, e o deus mosaico, nasceu a religião hebraica e o nome de Deus Pai único. Moisés também institui um ritual para ligação com seu Deus, a circuncisão que, segundo Freud (1996d), seria o substituto simbólico da castração que teria sido imposta pelo pai primitivo, como um sinal de aceitação e submissão a esse pai. Moisés tentou ganhar a simpatia dos judeus, enfatizando que eles seriam os escolhidos. No entanto, Moisés foi assassinado. O motivo seria a rejeição à nova religião. Todavia, segundo o 
psicanalista, houve um regresso do Deus pai na figura do Cristo. Uma oportunidade de universalização da nova religião.

A instauração da lei foi valorizada com a morte do pai, pelos filhos. O Cristianismo surge com a morte do Judaísmo. Nesse caso, a religião do pai foi substituída pela religião do filho. A religião do filho foi balizada em um sentimento de culpa desse filho, pelo assassinato do progenitor. Dessa forma, não haveria mais necessidade do ritual da circuncisão para manter a nova religião. Freud (1996d) assevera que bastaria a manutenção das experiências do trauma, da "tradição herdada" Freud (1996d, p.63), para estruturação do sujeito. Moisés fez o povo experimentar a ideia de um deus único, logo Moisés ocupou uma posição de apresentador desse deus ao povo. Nesse sentido, a figura paterna teria a mesma posição no Édipo, qual seja a de apresentar ao sujeito outro lugar.

Esse lugar, ocupado pela figura paterna, teria origem na experiência religiosa mosaica do Deus único. Segundo Freud (1996d), no poder real é que estaria a força do pai primitivo. Já Lacan (1995) explicitou que, ao contrário, na cultura ocidental, a autoridade do pai estaria ligada à experiência do Deus único, mas que esse Deus não estaria presente. Portanto, o poder desse pai ausente estaria exatamente em um vazio.

Lacan (1995) quer tentar articular sua fala em torno da angústia do pequeno Hans. Hans teria invocado a fobia para operacionalizar a castração, substituindo a função paterna pelo seu sintoma. Ele, Hans, utiliza a fobia para paralisar a angustia, valendo-se dos deslizes do significante cavalo e um medo que o cavalo caísse. O menino tinha um medo de que um cavalo pudesse mordê-lo na rua e o medo tem ligação com o fato de ele estar se assustando com um grande pênis. No caso Hans, Freud (1996a) manteve o pai como agente de castração do menino e não seu substituto: o cavalo. Lacan (1995) assinala que não é que o pai de Hans fosse bom ou ruim ou não fosse presente. Ele, o pai de Hans o leva na presença de Freud. No entanto, Hans só consegue resolver seu problema com a fobia. E é a falta de firmeza da palavra do pai que faz com que Hans tenha medo de cavalos, coices e quedas de cavalos. As palavras do pai não impunham receio em Hans. Portanto, a presença do pai seria fundamental no complexo de Édipo, para que o menino pudesse se libertar da posição de objeto imaginário do desejo da mãe. Tal fato impossibilitou a localização do pai para que Hans o reconhecesse como o portador da castração. Lacan (1995) revelou que o combustível para o enfraquecimento da função do pai real de Hans era o medo que Hans sentia do animal. Somam-se a esse evento os fatos de seu pai ser um homem bondoso e tolerante, 
e a mãe não fazer valer a palavra do progenitor de Hans. Esses elementos contribuíam para deixar Hans refém dos caprichos da mãe. Quem deveria privar a mãe de Hans do seu objeto de desejo seria o pai de Hans. No entanto, ela, a mãe, ainda nomeia outro para ameaçar Hans, ou seja, diz que o doutor irá cortar o pênis do menino, porque Hans se exibe para ela, e ela ordena que ele não ponha a mão no seu pênis. Somente pela fala de Freud, que era o doutor ameaçador, que o pai de Hans teve reconhecida sua palavra e ocupou seu lugar legitimado.

Lacan (1995) ainda expõe como o sujeito entra no Édipo. No caso de Hans, ele deve ser capturado por seu próprio engodo, ou seja, o menino se insinua para a sua mãe, mostra-se a ela como um chamariz. Assim, ele deverá ser capturado por sua atuação como isca. Dessa forma, ele poderá ser normatizado pelo Édipo. Entretanto, essa primeira ação não é suficiente para que a função do Édipo seja concluída. Esse sujeito deve ser direcionado a uma escolha de objeto. Adiciona-se a esse evento que a escolha de objeto deve ser heterossexual. Porém, mesmo sendo heterossexual, ainda há possibilidade de mascaramento dessa forma de escolha, que pode ocultar um arranjo homossexual. O ideal seria que a menina ou o menino, segundo Lacan (1995), tenha como referência para a sua escolha objetal, após passar pelo Édipo, a função do pai.

Seguindo esse raciocínio, Dor (1991) alerta que não há como pensar o Édipo sem a função do pai. Portanto, a função do pai seria conduzir o sujeito a uma dimensão significante, pelo processo do complexo de Édipo. Lacan (1995) pergunta: "O que é ser um pai? Ou, o que é um pai?” (LACAN, 1995, p.209). Dor (1991) responde, utilizando as ideias de Lacan (1995), que o pai é uma metáfora, já que não é um “objeto real”. E que a metáfora é um significante "que vem no lugar de um outro significante" (DOR, 1991, p.45). Assim, o sujeito se constitui por sua inscrição no simbólico. Para tanto, há necessidade de o sujeito ter condições de acesso ao mundo da linguagem. Lacan (1983) assinala que o sujeito ocupa o mundo do simbólico, da linguagem e que tal circunstância é dada pela fala.

Na mesma linha de pensamento, Françóia (2007) demonstrou que Lacan (1998) pretendia explicitar, através da produção de sua obra "Função e Campo da Fala e da Linguagem em Psicanálise”, os descaminhos que as obras freudianas “experimentavam” pelos seus seguidores. Para tanto, segundo a autora, o psicanalista deveria se tornar o Mestre das funções da fala. Lacan (1998) alerta que para utilizar qualquer conceito freudiano, se faz necessário um retorno a Freud. Nesse sentido, Lacan (1998) quer demonstrar que os conceitos freudianos só tomam sentido pleno, ao serem orientados 
em um campo de linguagem e ordenados à função da fala. A fala é considerada por Lacan (1998) como um norte necessário ao retorno a Freud. Portanto, o psicanalista deve ser um mestre das funções da fala para evitar um desarranjo na interpretação dos conceitos freudianos. Logo, conforme assinalado anteriormente, a fala definiria a situação de sujeito.

A porta de acesso do sujeito à dimensão significante é o complexo de Édipo. Para que a lei seja internalizada, e assim o integre à sexualidade, ele, o sujeito, deve passar pelo Édipo. Essa lei organizará a atuação desse sujeito no ambiente simbólico, isto é, ordenará o exercício de sua sexualidade nesse ambiente simbólico. Entretanto, para que ele obtenha o registro no ambiente simbólico, a metáfora paterna será o mecanismo primordial para a autenticação desse registro.

Lacan (1995) também examina a atuação do complexo de Édipo na menina. Ao contrário do menino, a menina encontra o pênis real no pai. Assim, ela não rejeita o objeto de quem tem o dom de realizar seu desejo. Desta forma, segundo o autor, "pela relação ao falo” (LACAN, 1995, p.207), a menina entra no Édipo, mas de um modo simplificado porque o falo deve ser deslocado do imaginário para o real, o que o psicanalista denomina como "equivalência”. O pai é o objeto de amor da menina. Nas palavras do autor é "o objeto do sentimento que se dirige ao elemento de falta no objeto que é o pai” (LACAN, 1995, p.207). Ele, o pai, transforma-se em dono do objeto que dará a criança à menina. Mas haverá nova substituição de objetos, ou seja, surgirá outro que fará o papel do pai e poderá dar-lhe uma criança.

Voltando ao caso de Hans, Lacan (1995) explicita que Hans se refere aos objetos que fazem "pipi", conforme mencionado anteriormente, principalmente os objetos dos adultos. Hans especula se seus pais têm um "faz pipi”. Observando a mãe inicialmente, Hans imagina que o “faz pipi” dela deveria ficar à mostra como o do leão, que ele havia visto. Mas, segundo o autor, isso se transforma em um jogo imaginário de Hans. Ele brinca de “fazer de conta” (LACAN, 1995, p.210). Hans fica equiparando os objetos e assim fica preso ao "plano imaginário" (LACAN, 1995, p.211). Entretanto, o jogo da isca continua, pois Hans não tem o principal referencial para entrada no Édipo: o seu pai.

Sem o referencial, o personagem da trama fica perdido. Ele quer dar nome ao objeto e não encontra meios para isso. Assim, o objeto fóbico de Hans, o cavalo, morde porque substitui o pai. Seria um pedido de socorro de Hans, para que fosse submetido à castração. Hans descobre a ligação do seu problema com a figura paterna, quando Freud 
faz o papel de pai simbólico. Lacan (1995) explicita que o pai simbólico é impensável. Segundo o autor poderíamos encontrar em “Totem e Tabu” a resposta sobre a localização do pai. Há uma necessidade de existência de um "verdadeiro pai, o pai singular, o pai único”, que “esteja antes do surgimento da história” (LACAN, 1995, p.215), para que os pais existam. Ao mesmo tempo, é preciso que este pai original esteja morto e que tenha sido assassinado pelos filhos. Assim, esse pai original morto daria subsídios ao pai real para o exercício da função.

Dor (1991) entra na discussão para assinalar que o investimento, pela criança, no pai simbólico, transforma o papel do pai real em secundário. Segundo o autor, se o Nome-do-Pai estiver presente no discurso da mãe, fazendo com que a criança entenda que o desejo materno está direcionado ao significante "pai”, ele será “presentificado como instância mediadora na ausência do Pai real” (DOR, 1991, p.57). No entanto, a criança deve perceber, pelo discurso da mãe, que não satisfaz o desejo materno, enquanto objeto fálico. A dúvida da criança em relação à alçada do pai, enquanto possuidor do falo e alvo do desejo da mãe poderá conduzi-la a uma estrutura perversa. Dor (1991) enfatiza que dessa forma, a lei do pai não será reconhecida, senão para ser contrariada, e ainda haverá um momento propício para que o “desafio e a transgressão” se instalem (DOR, 1991, p.62).

Ao percorrer parte do caminho trilhado por Freud e Lacan, para construção da noção de pai e de sua função, percebemos que houve uma articulação entre os referidos conceitos. Nas obras visitadas, verificamos que o pai para Freud em “Totem e Tabu” é o pai morto que se fortaleceu enquanto lei. Com sua morte, não houve necessidade de força para fazer valer a lei. O pai foi simbolizado. Os filhos, ao assassinarem o tirano imaginando destituí-lo de uma posição de poder, fortaleceram-no e o transformaram em pai. A lei ficaria internalizada com esse crime. Nesse sentido, a função do pai, segundo Freud (1996b), se tornou simbólica. Entretanto, com a morte do pai surgiu um sentimento de culpa, pela identificação dos filhos a esse pai morto. Assim, surge a lei.

Em “Moisés e Monoteísmo” (FREUD, 1996d), o autor demonstrou que o pai foi aquele que ocupou o lugar de filho. Moisés foi um filho abandonado, que se transformou em líder e ocupou o lugar do pai. Proveniente de família humilde que ascendeu a um lugar de líder, Moisés aplicou um regulamento rígido, em nome de seu Deus pai único, idealizou um ritual - a circuncisão - para obediência e submissão ao Pai e sofreu as consequências, foi assassinado pelos “filhos” seguidores. 
Para o autor do "Édipo", o pai é o obstáculo à realização do desejo sexual na relação entre mãe e filho. O pai para Freud (1996c) é aquele que deve estar no discurso da mãe. É aquele que transmite a cultura. É o sujeito que faz com que a criança renuncie a gozar-se através da mãe.

Com Lacan (1995) o pai adquire uma série de funções articuladas. Uma delas seria a de conduzir o sujeito a uma dimensão significante, pelo complexo de Édipo. O complexo de Édipo só seria superado pelo exercício da função paterna. Para o psicanalista francês, a função paterna também introduziria a proibição do incesto e daria acesso para o sujeito, ao mundo da cultura. Ela, a função paterna, também permitiria, no sujeito em constituição, o surgimento do desejo. A função paterna seria a que daria autenticidade à inscrição do sujeito no ambiente simbólico, ou seja, na presença do real, ela unificaria o imaginário e o simbólico.

\section{O declínio da função de professor}

O acesso ao mundo da cultura também é objetivo das instituições educacionais. Atualmente, as instituições educacionais mantêm uma relação com seus estudantes, considerando-os clientes que pagam por serviços educacionais. Vieira (2004) apresenta a questão da preocupação antiga das instituições de ensino e de seus professores em formar os estudantes como seres que necessitavam de conhecimento e orientação moral e religiosa. Essa educação de qualidade era de domínio de instituições religiosas. No entanto, segundo Vieira (2004) atualmente o cenário não é o mesmo. Hoje o empreendimento na área de educação é buscado por empresários com seus habilidosos profissionais em publicidade. Destarte, o conhecimento é construído como um produto para venda, para ser consumido. Nesse sentido, o produto comercializado é valorizado em detrimento do conjunto de estratégias pedagógicas e publicitárias. Segundo Vieira (2004) “o currículo esvaziou-se das disciplinas formadoras do caráter e da cidadania” (VIEIRA, 2004, p.119). As instituições de ensino funcionam como vitrines ilustradas e bem "iluminadas”, com belas imagens de equipamentos tecnológicos e de encontros virtuais, nos quais as relações são marcadamente mais superficiais do que no ambiente físico. O que importa é o lucro. O conhecimento é de responsabilidade da instituição educacional, a formação do estudante é com a família. À escola foi dada mais responsabilidade no sentido de cuidar da transição das fases de criança e adolescência 
para a vida adulta. É considerada fase de transição e de crises, de dificuldades em todas as etapas da vida humana. Logo, essas etapas não poderiam ser livres de embates e resistências pelo sujeito alvo das transformações impostas. Nesse sentido, ocorre uma transformação no papel do professor. Souza (1998 apud DIAS, 2002), alerta que a educação pode transformar em um instrumento perigoso, porque o professor, como formador de opiniões independentes, contribuiria para criticar o sistema capitalista. Segundo Dias (2002), houve uma desvalorização dos conhecimentos dos professores, que contribuíam para a transmissão da cultura, na qual pertenciam. Esses conhecimentos foram retirados dos professores, prejudicando seu valor social e simbólico e enfraquecendo sua prática docente.

Vimos como os argumentos de autores investigados foram utilizados para demonstrar os abalos da morte do pai e o declínio da função paterna, sobretudo com Freud e Lacan. Nesse sentido, poderíamos efetuar uma relação entre as análises desses autores à figura do professor, pois para a psicanálise o professor necessita se posicionar em um lugar de autoridade diante de seus estudantes, como uma forma de instigar a busca do saber. No entanto, o professor tem experimentado um desafio no sentido de ter que seguir determinações de novos atores que se inseriram na área de educação, que se especializaram na compreensão do ser humano e de como aprendem. As ciências fazem o papel do pai ditador que conhece bem as estratégias para o professor ser bem sucedido em sua função.

Freud e Lacan nos demonstraram que o pai, como representante da lei, necessitou se submeter a ela. O professor também deve ser o transmissor da lei, da cultura. Porém, ele, o professor está submisso ao pai ditador, as determinações dos especialistas, o que faz sua função ser desvalorizada, além das condições dos ambientes de ensino e a questão salarial, sem entrar em maiores detalhes, o que não é a intenção aqui.

Freud e Lacan nos demonstraram que a função do pai seria a de promover a simbolização do psiquismo da criança, propiciando a experiência de angústia para simbolizá-la e evitar a total dominação de suas ações. Portanto, a criança necessita se identificar imaginariamente com o pai, num primeiro momento. Esse sentimento poderá ser efetivado também com o professor, o estudante precisa ver no professor algo que o instigue a buscar o saber, a buscar o conhecimento. No entanto, não é o que percebemos. A História nos mostra que a figura do pai foi sofrendo alterações e tomando novos rumos. O pai para ser o representante da lei precisa se submeter a ela. o 
que percebemos é que há uma submissão às determinações de especialistas que entendem melhor dos filhos do que os próprios pais. Dessa forma, destituem o pai do seu lugar de autoridade. Da mesma forma a função de autoridade do professor é alvo de questionamentos, pois o discurso dos especialistas é que administra as atividades nas escolas.

Dias (2002) alerta sobre o excesso de atividades do professor, em função das determinações dos especialistas. Como não há uma organização de prioridades a sensação que o professor tem é de que não faz nada, não consegue acompanhar as diretrizes. Além do mais, para o caso de escolas particulares, a atenção deve ser totalmente para o estudante, que é o cliente principal, que deve sempre estar satisfeito com seu "produto" de consumo. Adicione-se a isso o fato da desvalorização da profissão de professor, sendo desprezada pela sociedade.

A psicóloga assinala que os estudantes transferem os ideais e expectativas relativos ao pai para o professor. Destarte, posicionam o professor no lugar de ideal-doEu. Inconscientemente o escolhem como exemplo que substitui a figura paterna.

Tentamos uma aproximação compreensiva acerca da morte do pai e do declínio da função paterna e acreditamos a da função de professor. Como esses fenômenos vêm ocorrendo ultimamente. Entretanto, apesar dos declínios, tais funções ainda persistem. Há necessidade de elaborações de novos encadeamentos do indivíduo com a cultura. Essas figuras, a paterna e a do professor, são alvos da sociedade como funções que estão expostas ao fracasso.

Vale ressaltar que não estamos procurando responsáveis pelos fenômenos que ocorrem nos ambientes escolares, tais como, fracasso escolar, evasão, violência etc. O que se percebe é uma situação análoga à do pai, o declínio da função do professor. Esse declínio da função docente é resultado do que ela representa para o estudante. É reflexo da falha da função paterna. O sujeito não foi, digamos “violentado” pela castração. A falta dessa "violência” da castração faz com que haja outra violência na relação entre o aluno e o representante simbólico da lei: o professor.

Retomando as ideias de Freud e Lacan acerca da noção de pai, observamos que a falta do pai castrador vem mostrar que, se o pai é o obstáculo, como Freud tencionava, não é somente porque ele impede que o investimento amoroso, ou relativo ao prazer sexual da criança em relação à mãe, se realize, o que significaria uma união sexual ilícita, mas antes - e fundamentalmente - porque o pai - enquanto terceiro da relação vem, por assim dizer, salvar a criança do risco de tornar-se o objeto do capricho 
materno, numa confusão dual e sem saída. Finalmente, a metáfora paterna é o que faz com que, aí onde havia apenas o objeto, advenha o sujeito desejante. Nessa medida, como interpretação da composição do Édipo freudiano, ela tem uma função, de algum modo, normatizante ou apaziguadora.

Porém, e em segundo lugar, parece restar aqui algo de impossível de apreender nesta questão do pai como que a fazer eco ao dito popular que sublinha que ele é incerto. É Lacan o primeiro a relembrá-lo numa passagem do Mito Individual do Neurótico. Diz ele: “a assunção da função do pai supõe uma relação simbólica simples, onde o simbólico recobriria plenamente o real” (LACAN, 1978, p.195).

A não coincidência fundamental entre o real e o simbólico traduz um intervalo ou uma inadequação irredutível entre esses dois registros. No fundo, o que está em causa é isto: as palavras, ou a linguagem, ao substituírem-se à coisa, hipoteticamente real primitivo e sem lei, deixam um rastro, na medida em que não há um velamento completo entre os dois registros. Seria possível dizer que esta primeira substituição não é mais do que a própria metáfora primordial da condição humana.

Relativamente a ela, a metáfora paterna constitui uma espécie de metonímia que em vez de suprimir o encontro fundamental entre o real da coisa e o simbólico, da fala e da linguagem, o desloca e, de alguma forma, o re-nomeia nesse espaço e nessa realidade particular onde o drama subjetivo se desenrola: a família. É daí que o Nome-do-Pai, que contém uma revelação interessante, retira a sua importância. Pelo contrário, todo o pai (real) apresenta-se sempre, ou a maior parte das vezes, como um pai de algum modo carente, humilhado, discordante relativamente à sua função, que seria simbólica.

É por isso que a questão do declínio da função paterna acaba por desembocar quase inevitavelmente nos sintomas presentes na adolescência. E esse é o sujeito “cliente” principal das instituições educacionais. Lacan (1985) dirá mais tarde, já na última fase do seu ensino que o pai é um sintoma. Mas já na passagem extraída do Mito Individual do Neurótico, Lacan falava do valor gerador de moléstia do Édipo. É como se houvesse na questão paterna uma espécie de encruzilhada ou de paradoxo fundamental: ao mesmo tempo em que nomeia e dá ideia, o que permanecia sem nome no sujeito, ele mesmo, enquanto tal mantém-se inominável; quer dizer: há algo impossível de nomear e, portanto, real, na avaliação de Lacan (1987a), a qual o real apresenta dificuldade, na função paterna ela mesma.

Para dar conta do que permanece aí de inapreensível, de real, Freud foi obrigado a utilizar, para além do Édipo, um novo mito: o Totem e Tabu. Tal invenção demonstra, 
e Lacan (1985) não deixa de sublinhar o fato, que o real pode ser mítico e mais forte que o verdadeiro. O real da realidade ordinária, realidade em que o real e o imaginário andam geralmente desordenados, é antes o que há de impossível de apreender ao nível da própria função paterna, na medida em que esta se refere ao real e não é forçosamente o verdadeiro do real. Daí o desejo de o estudante querer manter sua situação, ou seja, o prazer de fugir da realidade "dada” pela sala de aula e a de quem nela ocupa lugar de autoridade: o professor.

Não ser o verdadeiro do real significa, pelo menos, duas coisas: em primeiro lugar, que ele pode ser mítico, como vimos anteriormente, sem que, apesar disso, para a estrutura seja menos importante que o dizer verdadeiro, mas também que o próprio verdadeiro, em última análise, acaba por revelar-se como um buraco, uma impressão vaga, impossível de tapar. Quando buscamos o verdadeiro do pai, acabamos, inevitavelmente, por embrulhar-nos e escorregar nesse buraco. É neste sentido que Lacan (1985) falava da embrulhada do verdadeiro. O Real, dizia ele, encontra-se nas embrulhadas do verdadeiro.

Impossível de apreender inteiramente, ele está condenado a multiplicar-se: todos os nomes-do-pai (Édipo, Totem, Moisés... em Freud, Real, Imaginário, Simbólico...) procuram dar conta desse resto por nomear, mas nenhum deles é inteiramente capaz de fazê-lo. O real do pai permanece irredutível. E é nessa medida, também, que o real é mais forte, mais resolutivo que o verdadeiro, e que o sintoma é, finalmente, um dos seus nomes.

Lacan (1987b) propõe que a metáfora paterna é a responsável pelo surgimento do sujeito desejante, onde havia apenas o objeto, tendo, assim, função tanto normatizante quanto apaziguadora. O autor alerta também que o pai deve representar um valor simbólico pleno ao exercer sua função. Conclui que o complexo de Édipo é positivo, pois denuncia o mal-estar, e ainda, que a metáfora paterna contribui para o deslocamento e renomeação do encontro entre o real da coisa e o simbólico, da fala e da linguagem, e que ocorre num espaço particular, ou seja, na família. Daí, talvez, um motivo pelo qual os professores apontam a família como origem do fracasso dos estudantes na escola.

A guisa de conclusão, após apresentar as discussões, possibilitadas pela pesquisa e pelos autores trabalhados, com relação à noção de pai em Freud e Lacan, relacionando-a ao declínio da função do professor, percebi que, hoje, na sociedade globalizada, o ideal paterno não opera do mesmo modo, é mais fraco. 
Na convivência moderna, temos o médico, o professor, o pediatra etc que, em suas funções, representam autoridades na vida de uma criança e de um jovem. Quando uma autoridade se multiplica, ela enfraquece. Então, qual é a função do pai? Quando a criança continua a perguntar - por quê? Por quê? - de certo modo, somente o pai pode dizer é assim, porque é assim. E, portanto, com a multiplicação dessas autoridades na vida dos sujeitos, a função paterna se enfraquece e declina.

Desta forma, define-se a função do pai no ser falante. O pai está na linguagem, é um significante, ilustra uma função lógica. É por estar morto como apego ao real, à etimologia do termo, que a ideia do patriarca, que se faz equivalente a um puro significante, está cada vez mais relegada a uma posição menos expressiva, passando a ênfase maior a recair sobre o pai simbólico. O pai é aquele que articula a lei. Ou ele falta como presença ou como presença está presente demais ou ainda, mesmo presente ele falha.

É preciso reconhecer no pai a castração; para isso, é preciso que ele reconheça a sua própria castração. Porém, o que é isso? É uma posição diante da falta do Outro. É de pai para filho que se transmite a castração, quando ele escolhe uma mulher, como objeto causa de desejo, e a transforma em mãe. Segundo Lacan (1987b), um pai só tem direito ao respeito e ao amor, se esse amor e o respeito estiverem verticalmente orientados, isto é, feito de uma mulher, objeto pequeno 'a', que causa seu desejo. É enquanto esta mulher se torna mãe de seus filhos, que este pai é nomeado como função. Por consequência, essa mulher se ocupa de outros objetos pequenos e que são as crianças, junto a quem o pai, então, tem a função de intervir. É dessa forma, então, que se reconhece nesse pai a função da castração. Só dessa forma é que pode ocorrer a transmissão do desejo do pai para filho.

Neste início de século, constata-se uma crise do lugar do pai e de sua função de nomeação. Neste declínio da função paterna, estranhamente o social vem fazer suplência a essa falha da nomeação paterna. Lacan (1985) assinala que ser nomeado de alguma coisa, é o que coloca uma ordem que se encontra efetivamente em se substituir ao nome do pai.

Por outro lado, o pai talvez já combalido no tempo de Freud, agora não dispõe de nenhum trono, mas está, pelo contrário, também perdido no grande redemoinho do consumo, humilhado pela perda das prerrogativas com as quais, de qualquer forma, sequer poderia arcar sufocado pelo imperativo da igualdade e do diálogo compulsório 
entre ele e os filhos; e é bem possível que, de vez em quando, ele se encontre com um dos seus filhos deprimidos.

Nas instituições educacionais, as dificuldades de relacionamento se manifestam com os outros estudantes, com os professores e diretores, e isso se configurou pela discussão realizada como efeito do declínio da função paterna. Atualmente, mesmo que o professor tenha bom domínio do conteúdo, consciência profissional, desejo real de levar os alunos à aprendizagem e formação didática, os resultados não são sempre positivos. É preciso remarcar que a relação professor e aluno é componente importante no aprendizado efetivo e, portanto, precisa ser compreendida na sua integridade.

A presente pesquisa e todos os autores estudados, em relação ao objeto a que me propus investigar, foram-me de grande valia, pois me levaram a perceber que a morte do pai e o declínio da função paterna, podem ser citados como fatores responsáveis pelas dificuldades de relacionamento entre os jovens, na dita adolescência, e entre estes e seus professores, e que ainda podemos relacioná-lo ao declínio da função de professor.

Formulado esse entendimento, apresento como recomendações necessárias aos que lidam com a gestão do sistema nas instituições educacionais, aos professores e aos aprendizes, que fiquem sempre atentos para a ocorrência dos fatores citados e, ao sinal de que estão acontecendo, reforcem o diálogo, exercitem a paciência, se empenhem em estabelecer uma relação capaz de favorecer o crescimento conjunto, procurando por conhecer, suprir o crucial declínio do pai-limite, tornando mais significativas as cobranças por desempenho adequado de papéis e menor o peso das pressões sociais sobre todos.

Vale ressaltar que a qualidade de uma instituição escolar depende do modo pelo qual ela enfoca o processo de condução das atividades que se desenvolvem nas salas de aula. É o lugar no qual se realiza o processo de ensino-aprendizagem, mas também é a oportunidade que temos para desenvolver e promover os valores humanos nos estudantes. Tal qualidade depende, a meu ver, também da capacidade dos professores de estimular o esforço dos estudantes.

Outra questão de grande monta é a visão de mundo que professor passa aos estudantes. Percebi que esta fica enraizada nos estudantes mais que os conteúdos. A sala de aula é onde o professor tem oportunidade de propor discussões, despertar inquietações com relação à vida e formar opiniões. Aquilo que o professor demonstra ser influenciará o estudante, mais que ensina. O professor, representante da lei, contribui para formar indivíduos que tenham condições de desenvolver habilidades intelectuais, 
morais, físicas e sociais, portanto, deve ser cauteloso quanto à sua postura em seu trabalho.

Esta pesquisa também me possibilitou a compreensão de que há um equívoco em acreditar que a solução dos problemas da educação estaria numa geração de supercomputadores, que com apenas um clique colocaria o estudante em contato com tudo que necessita saber, resolvendo assim as mazelas da educação global. O contato humano, a meu ver, é insubstituível.

Entendo que estudantes e professores serão eternos aprendizes. O que é urgente é fazer com que o estudante perceba que a cada dia que passa sua educação dependerá de seu próprio interesse e de sua disposição para o aprendizado e constante atualização. O conhecimento teórico é importante para o ensino, mas a habilidade, o saber fazer é fundamental para que o estudante tenha competência para a resolução das situaçõesproblema com as quais se deparará. Neste momento, o estudante demonstrará se houve ou não o aprendizado.

Não podemos prever o futuro de uma instituição educacional, nem tampouco a escola do futuro, mas poderemos problematizá-lo. Porventura a instituição educacional poderia ser um lugar onde se aprenderia pelo trabalho e não para o trabalho? Onde se estimularia o gosto pelo aprendizado? Onde a determinação perpassasse as competências e habilidades dos alunos? Essas transformações contribuiriam para se repensar a construção de uma instituição educacional futura ou um futuro da instituição. Talvez assim, o avanço tecnológico seria um aliado da educação e não um entrave nas relações humanas.

Aproveito ainda para alertar sobre mais um fator primordial, ou seja, mostrar para os estudantes que o papel do professor não é ser investigador dos atos condenáveis escolares, e sim, fazê-los compreender que seus relacionamentos serão mais harmoniosos quando melhor se conhecerem. Para isto, há que se desenvolver o autodidatismo, o autoconhecimento, o desejo de aprender mais, aprender sobre tudo. Este conhecimento, buscado e apreendido, será importante para que o estudante se reconheça como pessoa modificada.

\section{THE DEATH OF THE FATHER AND DECLINING ROLE OF TEACHER}


ABSTRACT: This article is a reflection on some aspects that contributed to the "death" of the father and the declining role of teacher. The factors that influenced the changes in the constitution of the notion of father in Freud, in the construction of the concept of the paternal function in Lacan, and the reflection of the place occupied by the teacher as a symbolic operator of the Law It will explain the effects on relationships between teachers and students in educational institutions. It is proposed to explain how the teacher, while symbolic operator of the Law takes the place of the father and also loses its function. This research is the result of literature research involving the notion of father, castration, the names of the parent-and the concept of the paternal function. We conclude by explaining how the phenomena listed above were weakening and confusing the symbolic father and was reflected in the declining role of teacher.

KEYWORDS: Notion of father. Castration. Paternal function.

\section{REFERÊNCIAS}

DIAS, A. E. Novas configurações no contexto escolar: o que, de fato, o professor tem a ver com isso? In: COLÓQUIO DO LEPSI IP/FE-USP, 4., 2002, São Paulo. Anais eletrônicos... São Paulo: IP/FE-USP, 2002. Disponível em:

$<$ http://www.proceedings.scielo.br/scielo.php?script=sci_arttext\&pid=MSC0000000032 002000400001\&lng=pt\&nrm=isso\&tlng=pt > . Acesso em: 12 fev. 2014.

DOR, J. O pai e sua função em psicanálise. Rio de Janeiro: Jorge Zahar, 1991.

FRANÇÓIA, C. R. O Simbólico e a clínica psicanalítica: o início da teoria lacaniana. Revista AdVerbum, Limeira, v.2, n.1, p.87-101, jan./jun. 2007. Disponível em: $<$ http://www.psicanaliseefilosofia.com.br/adverbum/Vol2_1/o\%20simbolico\%20e\%20a \%20clinica.pdf>. Acesso em: 12 fev. 2014.

FREUD, S. Duas histórias clínicas: “o pequeno hans” e o "homem dos ratos” [1909]. v.X. Rio de Janeiro: Imago, 1996a. Edição Standard Brasileira das Obras Completas de Sigmund Freud.

Totem e Tabu [1912/13]. v.XIII. Rio de Janeiro: Imago, 1996b. Edição Standard Brasileira das Obras Completas de Sigmund Freud.

A dissolução do complexo de Édipo [1924]. v.XIX. Rio de Janeiro: Imago, 1996c. Edição Standard Brasileira das Obras Completas de Sigmund Freud.

Moisés e o Monoteísmo [1939]. v.XXXIII. Rio de Janeiro: Imago, 1996d. Edição Standard Brasileira das Obras Completas de Sigmund Freud.

LACAN, J. Nomes-do-pai. Rio de Janeiro: Jorge Zahar, 2005. (Série Paradoxos de Lacan).

Função e Campo da Fala e da Linguagem em Psicanálise. In: Escritos.

Rio de Janeiro: Jorge Zahar, 1998. p.101-187. 
Zahar, 1995.

O seminário: livro 4: A relação de objeto [1956/57]. Rio de Janeiro: Jorge O mito individual do neurótico [1953]. Lisboa: Assírio \& Alvim, 1987a.

Os complexos familiares na formação do indivíduo. Rio de Janeiro: Jorge Zahar, 1987b.

O sintoma. Porto: Assírio \& Alvin, 1985. Seminário 1: os escritos técnicos de Freud. Rio de Janeiro: Jorge Zahar, 1983. O seminário: livro 2: o eu na teoria de Freud e na técnica da psicanálise. Rio de Janeiro: Jorge Zahar, 1978.

LAPLANCHE, J.; PONTALIS, J.-B. Vocabulário da psicanálise. São Paulo: Martins Fontes, 2001.

PEREIRA, M. E. C. Pânico e desamparo: um estudo psicanalítico. São Paulo: Escuta, 2008.

VIEIRA, M. C. Fundamentos históricos, políticos e sociais da educação de jovens e adultos: aspectos históricos da educação de jovens e adultos no Brasil. v.1 Brasília: Universidade de Brasília, 2004. 